\title{
Proposal of a Laboratory-Scale Anaerobic Biodigester for Introducing the Monitoring and Sensing Techniques, as a Potential Learning Tool in the Fields of Carbon Foot-Print Reduction and Climate Change Mitigation
}

\author{
Saulo Brito-Espino ${ }^{1}\left(\mathbb{D}\right.$, Federico Leon ${ }^{1, *(\mathbb{D})}$, Jenifer Vaswani-Reboso ${ }^{1}\left(\mathbb{D}\right.$, Alejandro Ramos-Martin ${ }^{2}(\mathbb{D}$ \\ and Carlos Mendieta-Pino ${ }^{1}$ (D) \\ 1 Institute of Environmental Studies and Resources (IUNAT), Campus Tafira, University of Las Palmas de Gran \\ Canaria, 35017 Las Palmas de Gran Canaria, Spain; saulobrito09@gmail.com (S.B.-E.); \\ jenifer.vaswani@ulpgc.es (J.V.-R.); carlos.mendieta@ulpgc.es (C.M.-P.) \\ 2 Departament of Process Engineering, Campus Tafira, University of Las Palmas de Gran Canaria, \\ 35017 Las Palmas de Gran Canaria, Spain; alejandro.ramos@ulpgc.es \\ * Correspondence: federicoleon@perezvera.com; Tel.:+34-6861-69516
}

Citation: Brito-Espino, S.; Leon, F.; Vaswani-Reboso, J.; Ramos-Martin, A.; Mendieta-Pino, C. Proposal of a Laboratory-Scale Anaerobic Biodigester for Introducing the Monitoring and Sensing Techniques, as a Potential Learning Tool in the Fields of Carbon Foot-Print Reduction and Climate Change Mitigation. Water 2021, 13, 2409. https://doi.org/10.3390/w13172409

Academic Editor: Hongyu Ren

Received: 4 August 2021

Accepted: 29 August 2021

Published: 1 September 2021

Publisher's Note: MDPI stays neutral with regard to jurisdictional claims in published maps and institutional affiliations.

Copyright: (c) 2021 by the authors. Licensee MDPI, Basel, Switzerland. This article is an open access article distributed under the terms and conditions of the Creative Commons Attribution (CC BY) license (https:// creativecommons.org/licenses/by/ $4.0 /)$.

\begin{abstract}
This article presents a proposal of an anaerobic biodigester on a laboratory scale for introducing the monitoring and sensing techniques of the growth of microorganisms according to different parameters, where the redox potential, $\mathrm{pH}$, pressure, and temperature have been measured in quasi-continuous mode. For this task, a microcontroller system was used (Atmega328-Arduino). Importantly, the design is based on flexible and open-source software, hardware, and firmware (Scilab, Arduino, Processing), facilitating its modification for other related studies. This design was developed to help engineering students to learn and to understand the operation of an anaerobic biodigester, which allows us to know various properties of the system at any time, as well as its evolution over time. In this way, property curves can be drawn and related to each other to obtain a better understanding of the biodigester operation. In this context, the relationship between the oxide-reduction reaction and microbial activity was studied so that the redox potential can be a way of measuring the growth of microorganisms in an anaerobic environment. With all this, through these parameters, it is possible to introduce to engineering students the operation of this technology used normally like a very powerful tool for the control of the carbon footprint, for example in wastewater sector, and consequently for the mitigation of the climate change.
\end{abstract}

Keywords: wastewater; low-carbon; biodigester; laboratory scale; open-source tools

\section{Introduction}

Anaerobic digestion technologies, applied to organic water treatment, are efficient ways to solve environmental problems also provide energy. They are considered sustainable, safe, and efficient biotechnologies in which carbon footprint reduction, by $\mathrm{CH}_{4}$ capture and fossil fuel replacement, is clearly a factor to take under advisement [1-7]. The process of anaerobic digestion has been known and applied since ancient times; however, it was understood in terms of its final products and not its processes [3]. The versatility of anaerobic digestion applied as an effective technology in the face of certain fundamental challenges has found its usefulness in biotechnological industries [4-7]. Unlike aerobic processes where dissolved oxygen can be measured continuously, there is a great challenge for fermentative processes in anaerobic organisms where the technologies referring to control processes are currently insufficient [6-10]. Since $\mathrm{pH}$ detection has been commonly used in fermentation processes, where only the activity of the proton is reflected, it is not sensitive to small changes in the intracellular metabolism. The redox potential (ORP) known as 
oxidation-reduction or oxide-reduction potential, reflects all the electrons transferred and reflects the intracellular metabolism [6,11-15].

Recent advances in analytical technologies allow complex bioconversion processes to be controlled and deciphered. Few parameters in this process are routinely recorded continuously and immediately, such as $\mathrm{pH}, \mathrm{ORP}$, gas production rate, and flow rates [16-19].

Within this context, and due to the great number of applications that are being given to the anaerobic biodigesters, that is why it would be necessary to develop a strategy so that the engineering students could understand and develop its operation as well as the parameters that govern it, all applied to different situations. The learning of these strategies could be achieved using this equipment or through experimental designs carried out by students. This educational proposal is based on theoretical psychological studies published in numerous articles $[5,7,8,20-24]$ which emphasize that students can reinforce their learning through an appropriate teaching environment, as well as through the use, construction, and design of equipment.

After describing the importance of the anaerobic process and the consequent need to control it, at all times, the decision was taken to present the design and manufacture of an anaerobic batch biodigester on a laboratory scale, as well as its implementation through a practical application in which brewer's yeast (Saccharomyces cerevisiae) was introduced, and it was subjected to a semi-continuous control process, the results of which were subsequently compared with a previously proposed theoretical model [25-30].

The main objective of this article is to show an experimental design at laboratory scale of an anaerobic biodigester. In the same way, a series of tools, software, and hardware are proposed, which are easy to use and of low cost, and which will allow engineering students to see that they can develop autonomous elements to control an element, as well as to transform the information received into parameters that can later be interpreted in a computer [31-34]. The specific objective of this research is to relate the process of anaerobic digestion in a sequentially loaded reactor on a laboratory scale for a known microorganism and with a substrate prepared in the laboratory, to the profiles of oxidation-reduction potential, $\mathrm{pH}$, temperature, and absolute pressure [35-39].

\section{Materials and Methods}

\subsection{Diagram of the Laboratory Reactor}

The designed bioreactor (Figure 1) can be grouped into three distinct parts: (1) Digestion system - which includes the digester itself, as well as those elements that are in direct contact with it (sensors, heating cable, loading, and unloading supply, etc.); (2) Control system, circuits, and voltage source-it receives data and sends the orders necessary for the proper functioning of the system; and (3) Computer system, communication interface and software [40-44].

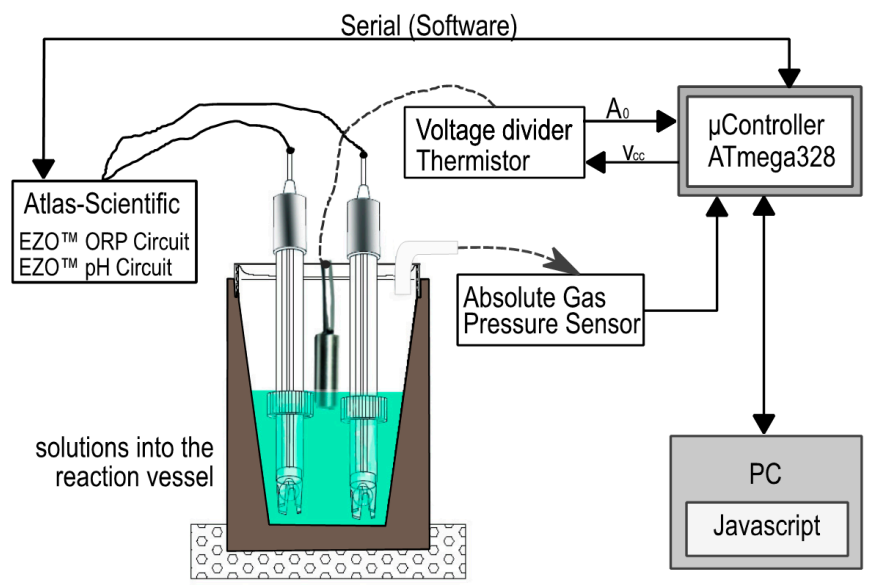

Figure 1. Basic diagram of experimental design. 


\subsubsection{Digestion System}

It is made up of an insulated hermetic container, with a feeding and evacuation system arranged so that the mixture is guaranteed in each loading and unloading process. The upper part of the container has a series of sensors that are defined below:

- $\quad \mathrm{pH}$ Sensor: Scientific Grade Silver/Silver Chloride $\mathrm{pH}), 10$ sensor with a response speed of $95 \%$ in one second.

- ORP sensor, (E): High quality sensor from Atlas Scientific [10,45-48]. The data transmission mode is through an integrated system and with a simple serial communication protocol which gives us an immediate response of the $\mathrm{E}$ value.

- Absolute Pressure Sensor: Phidgets mod. 1141-0—Absolute Sensor of gas pressure from 15 to $115 \mathrm{kPa}$ [49,50]. This is a high-level sensor with analogue input, with input proportional to the of the environment. The pressure measurement for this sensor is $15 \mathrm{kPa}$. The formula used to translate the sensor value into pressure was the following $[2,51,52]$ :

$$
\text { Pressure }(\mathrm{kPa})=(\text { Sensor Value } / 9.2)+10 .
$$

- Temperature sensor: Two miniature Vishay NTC thermistors (Figure 2) were used to take external and internal temperature readings. Their main characteristics are described in Table 1.

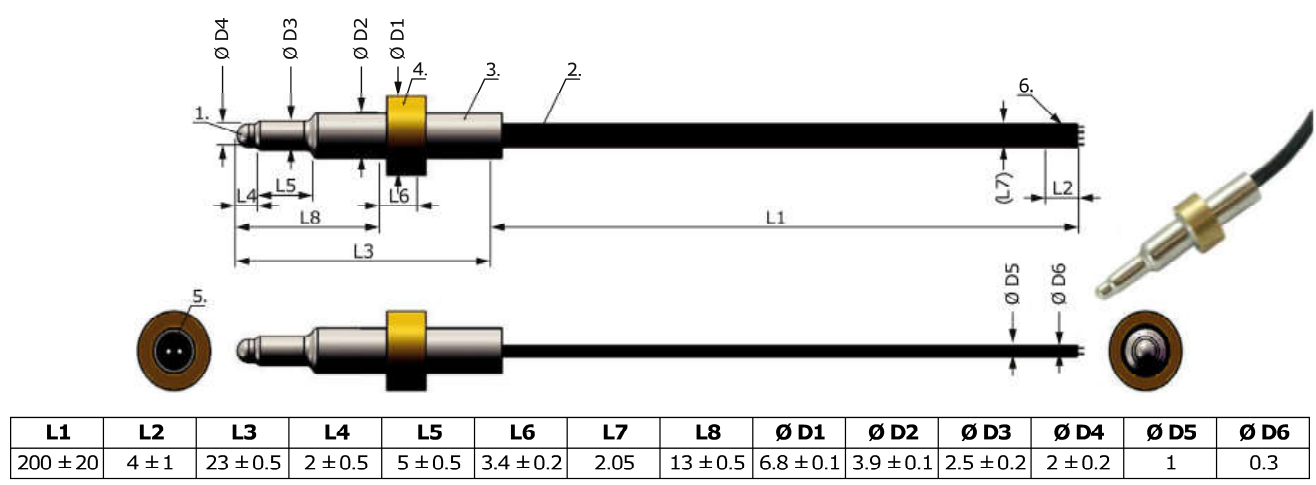

Figure 2. Thermistor NTC Vishay, dimensions in millimeters.

For the calculation of the temperature from the analogical measurement, considering the resistive values depending on the temperature provided by the manufacturer, and with an algorithm in Scilab, we obtain Equation (2).

$$
f(x)=2.249 \times 10^{-5} x^{2}+0.06872 x-16.03
$$

Table 1. Characteristics of the thermistor NTC, Vishay.

\begin{tabular}{ccc}
\hline Parameter & Value & Units \\
\hline Resistence value at $25^{\circ} \mathrm{C}$ & $10 \mathrm{~K}$ & $\Omega$ \\
Tolerance of 255 & \pm 3 & $\%$ \\
B25/85 (Beta) & 3984 & $\mathrm{~K}$ \\
Temperatura range of operation & -25 to 105 & ${ }^{\circ} \mathrm{C}$ \\
\hline
\end{tabular}

\subsubsection{Circuits and Control System}

Arduino Uno (Figure 3) microcontroller model ATmega328 (Atmel) was implemented within an embedded system in order to control the measuring processes providing bidirectional communication with the circuit of the electrical conductivity probe, transferring the respective data to the PC via USB for archival purposes. 

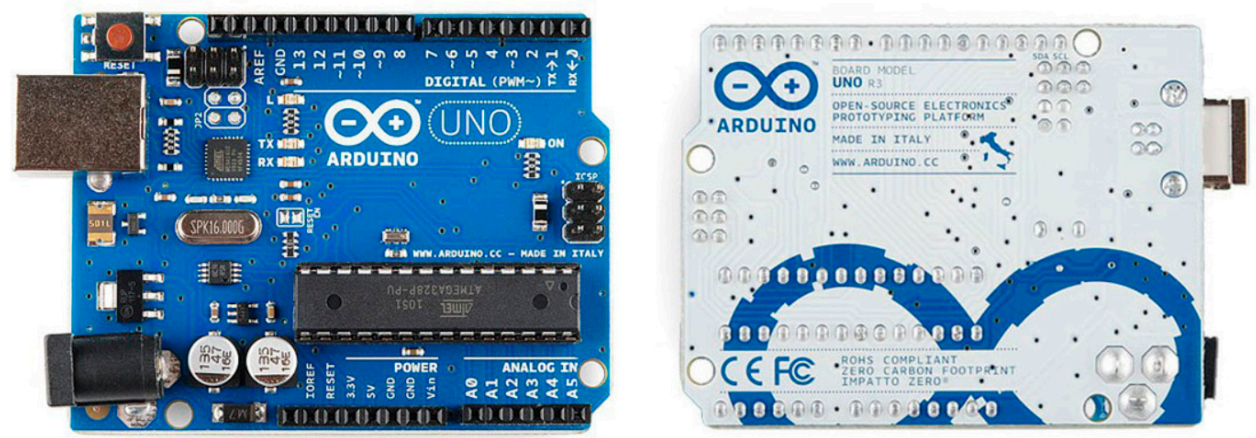

Figure 3. Arduino Uno.

Figures 4 and 5 show the general circuit diagram and pictures where all the elements necessary for the correct operation of the system are collected, as well as the data collection to be processed later. It is composed of a voltage source of $12 \mathrm{~V}$ that feeds: the transistor, a heat source, thermistors and a stirring system, a microcontroller hard plate, a PWM plate through which the bioreactor temperature is controlled by a transistor, a plate for the temperature sensors, auxiliary connection plates and sensor plates, resistors, diodes, and wiring.

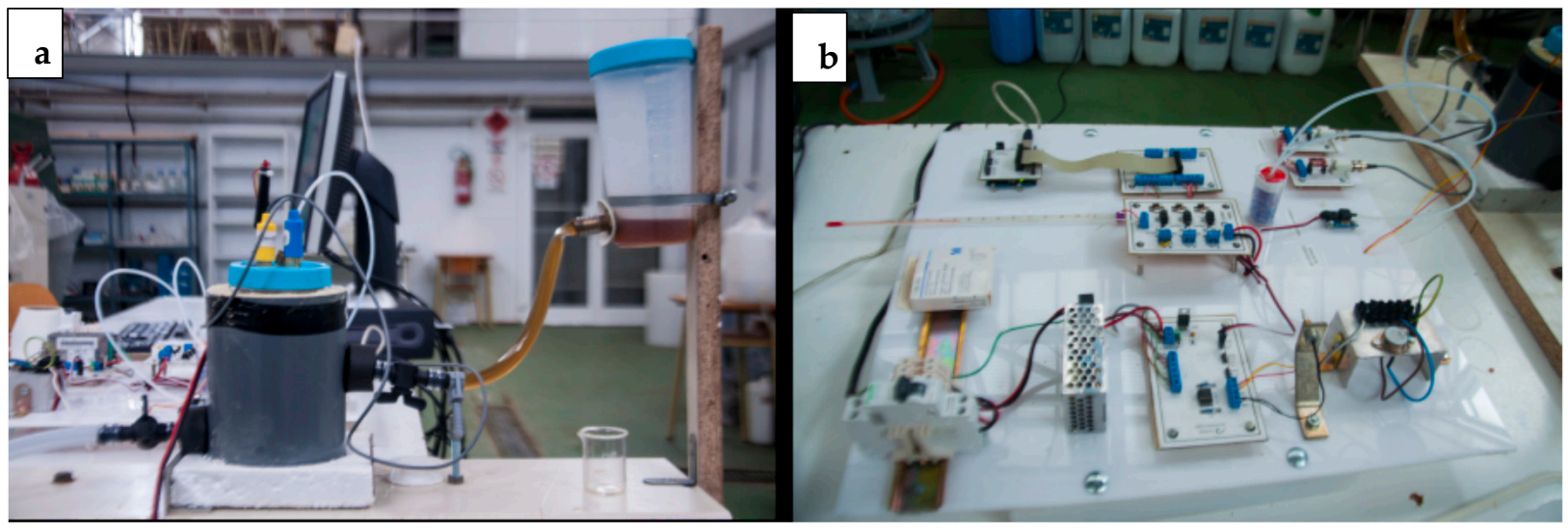

Figure 4. Photos of the reactor and sensors (a) and the circuits with the controls systems (b).

\subsubsection{Computer System, Communication Interface, and Software}

As for the computer system, a data transmission source code was developed for the $\mathrm{pH}, \mathrm{E}$, pressure, and temperature sensors with Processing software (source code in Appendix C). The output data was transferred to the Arduino ide serial monitor for checking and control, and then through the Processing software interface for saving into file the sensor samplings.

\subsubsection{Auxiliary Equipment and Laboratory Material}

The auxiliary equipment were the following: an Atago RX-7000 Alfa3 refractometer used for the effluent measurements, the refraction product, and the Brix degrees $\left({ }^{\circ} \mathrm{Bx}\right)$; and precision weights. As far as materials are concerned, all those related to the sampling and measurement of volumes (typical of a laboratory) were used, such as flasks, pipettes, spoons, etc. 


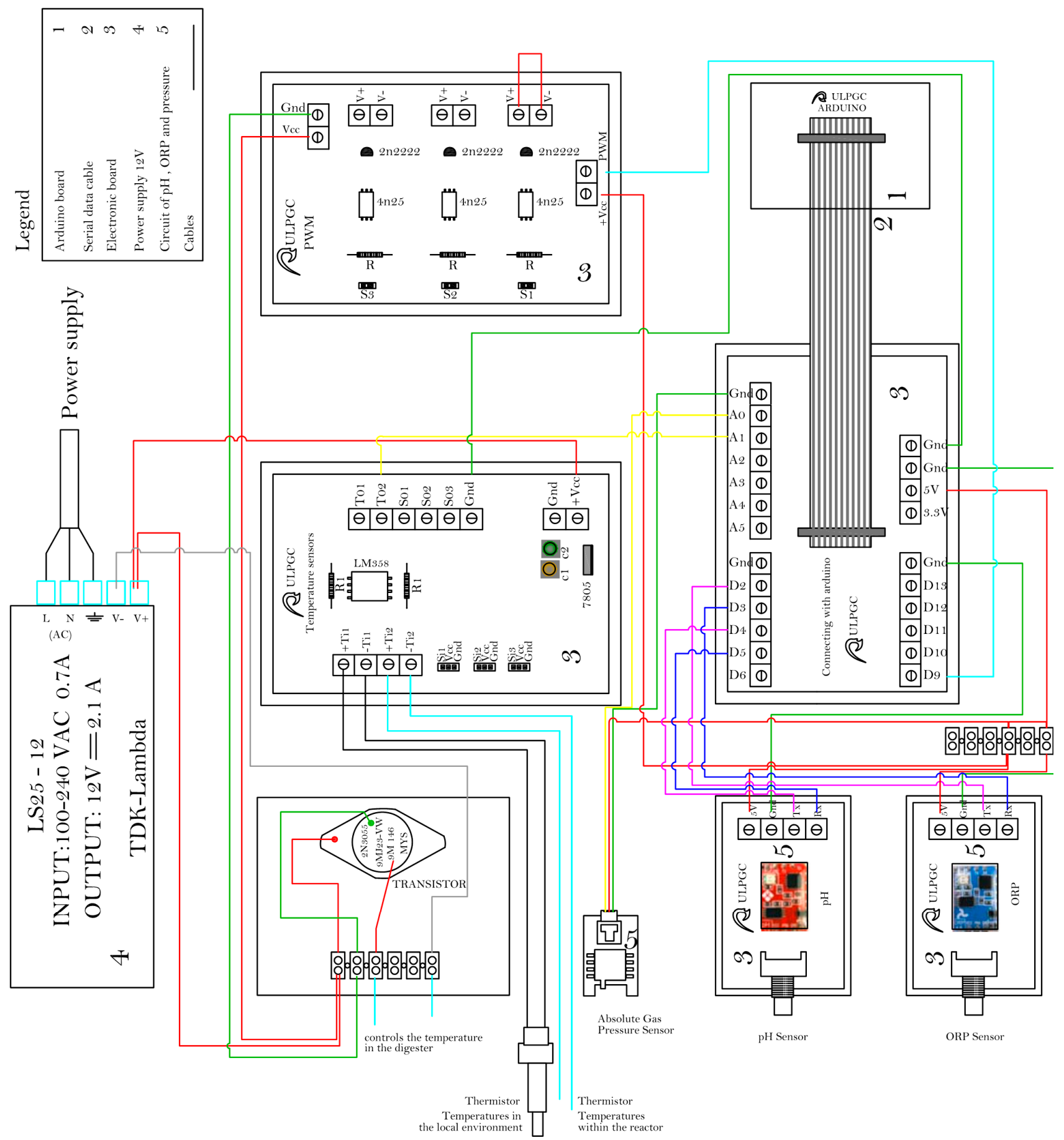

Figure 5. Circuits and control system design.

\subsection{Preparation and Testing}

\subsubsection{Preparation of the Substrate}

For the preparation of the substrate, the procedure described in bibliography was followed [4]. (1) The substrate was prepared, and its suitability checked. (2) The Brix level was measured and verified to be between 17 and 20 degrees. (3) Once this process was finished, $200 \mathrm{~mL}$ of the must was taken, and the yeast was added to it (approximately $2-4 \mathrm{~g} / \mathrm{L}$ ). Although an activation temperature of $37^{\circ} \mathrm{C}$ is normally required, it was left at room temperature, as it has been previously proven that the inoculum is active under these conditions for working yeast. 


\subsubsection{Microbial Inoculum}

Brewer's yeast was used whose species includes Saccharomyces cerevisiae with a yield of $0.25-0.33 \mathrm{~kg}$ of dry cell weight per $\mathrm{kg}$ of substrate.

\subsubsection{Control and Saving Data}

Through the Arduino (Appendix B shows the Arduino source code), the temperature was controlled and the signals from the $\mathrm{pH}$, ORP, absolute pressure, and temperature sensors (inside the digester and outside the environment) were read. Data were sent to the computer where they were stored by means of the use of Processing tool. Shown in Appendix $C$ is the Processing source code, and Figure 6 displays the interface. Once all the information was entered, it was saved in a file on the computer's hard disk.

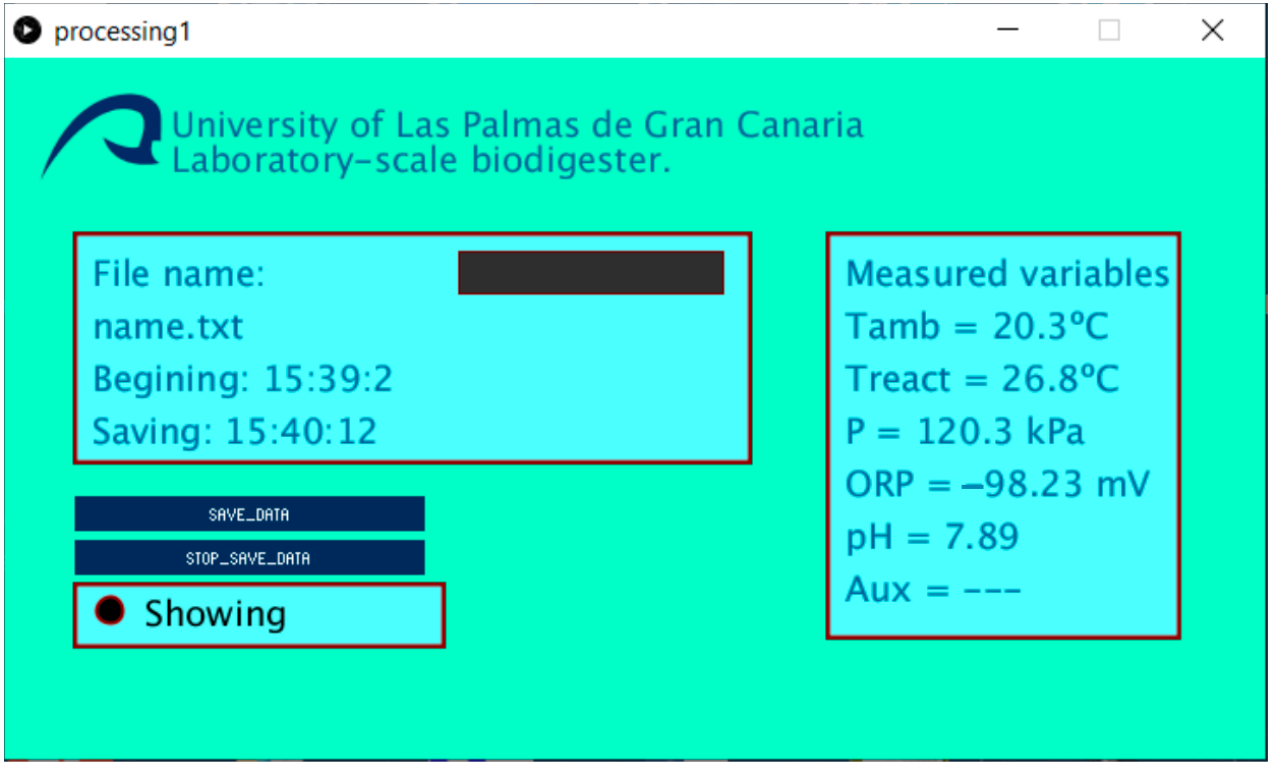

Figure 6. Processing PC interface data logger.

\section{Results}

\subsection{Digestion Model}

Dynamic simulation between reality and model is a very important way for research, as it enables to provide strategies for the digester operation. In the model, the description of all metabolic rates is based on the classical Monod equation,

$$
\mu=\mu_{\max } \frac{S}{K_{S}+S}
$$

where $\mu$ is the growth rate of a considered biomass, $\mu_{\max }$ is the maximum growth rate of this microorganism, $S$ is the concentration of the limiting substrate $S$ for growth, $K_{s}$ is the half-velocity constant for the substrate $S$ when $\frac{\mu}{\mu_{\max }}=0.5$.

The matrix differential equation related to biomass and substrate dynamic is as follows:

$$
\begin{gathered}
\frac{d X}{d t}=\left(\mu_{\max } \frac{S}{K_{s}+S}\right) X \\
\frac{d S}{d t}=\left(\beta_{s} \mu_{\max } \frac{S}{K_{S}+S}\right) X
\end{gathered}
$$

where $S$ and $X$ are the substrate and biomass concentration respectively, $\beta_{S}$ is the stoichiometric ratio for $S$. 
Figure 7 shows a simulation with discontinuous dynamics (Scilab source code in Appendix A) with period $\mathrm{T}=24 \mathrm{~h}$. Both the evolution of the substrate and that of the biomass, as can be seen in the system, start from an initial state and, after the transitory process, reach a stationary state.

\section{Temporal evolution}

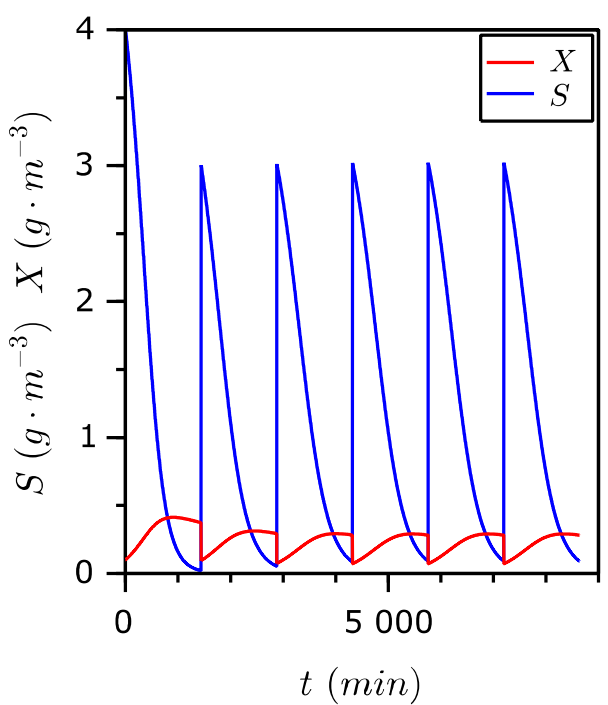

Phase portrait

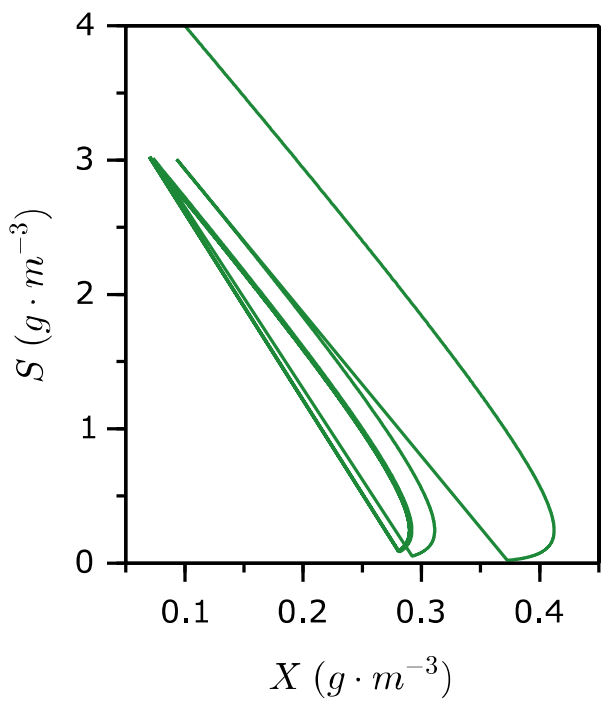

Figure 7. Concentration of biomass and substrate where $\mu_{\max }=0.75\left(\mathrm{~h}^{-1}\right), K_{s}=10, \beta_{s}=1.8, X_{(\mathrm{t}=0)}$ is $0.1\left(\mathrm{~g} / \mathrm{m}^{3}\right)$ and $S_{(\mathrm{t}=0)}$ is $4\left(\mathrm{~g} / \mathrm{m}^{3}\right)$.

\subsection{Anaerobic Digester Start-Up and Operation}

An average representation of the tests, carried out in the biodigester over 5 weeks, is shown in Table 2. The data was processed using a computerised tool from Scilab. Scilab is a software for numerical analysis, with a high-level programming language for scientific calculation. With the obtained data, a series of graphs were elaborated and the most relevant ones are presented in Figures 8-10.

Table 2. Laboratory-scale biodigester; performance periods, operating volume, and Brix measures.

\begin{tabular}{ccccccc}
\hline Stage & Date & Feeding/Evacuation & Brix Grades & & Remarks \\
\hline & & $(\mathbf{m L})$ & 1st Lecture & 2nd Lecture & Average & \\
\hline 1 & 13 June & 300 & 20.30 & & 20.30 & \\
3 & 18 June & 75 & 20.31 & 20.29 & 20.30 & Addition NaOH ( $\uparrow$ alkalinity) \\
\hline
\end{tabular}

The expression of the oxidation-reduction reactions can be expressed by the Nernst Equation (3).

$$
E=E^{0}+\frac{2.303 R T}{n F} \log _{10}\left(\frac{\text { Product of activities of oxidized species }}{\text { Product of reduced species activities }}\right)
$$

where $E^{0}$ is the standard ORP, $n$ is the number of exchanged electrons, and $F$ is the Faraday constant $(96.42 \mathrm{~kJ} / \mathrm{g}$ equivalent volts).

The three periods from Table 2 are represented in the graphs as they are the most illustrative. It had taken a time of 1-3000 min for each of them.

\subsubsection{First Stage}

This stage includes from the start-up of the bioreactor to the first charge/discharge process. Figure 8 shows the ORP, $\mathrm{pH}$, and temperature versus the time, in minutes. The 
$\mathrm{pH}$ profile remains stable with adequate value for fermentative processes, around 4.4, with slight oscillations, while the ORP values indicate, practically, reducing conditions, in a slightly wider range that the previous one. This last achieves its maximum value, $100(\mathrm{mV})$, at $1000 \mathrm{~min}$, and minimum value, $-250 \mathrm{mV}$ at $1300 \mathrm{~min}$; however, it tends to stabilize with fermentation time. This performance is reflected as well in other works $[53,54]$. On the other hand, during the whole of this period, temperature moved between 23.6 and $24.6{ }^{\circ} \mathrm{C}$. It is observable that for high value of temperature, the ORP 's graph tends to drop.
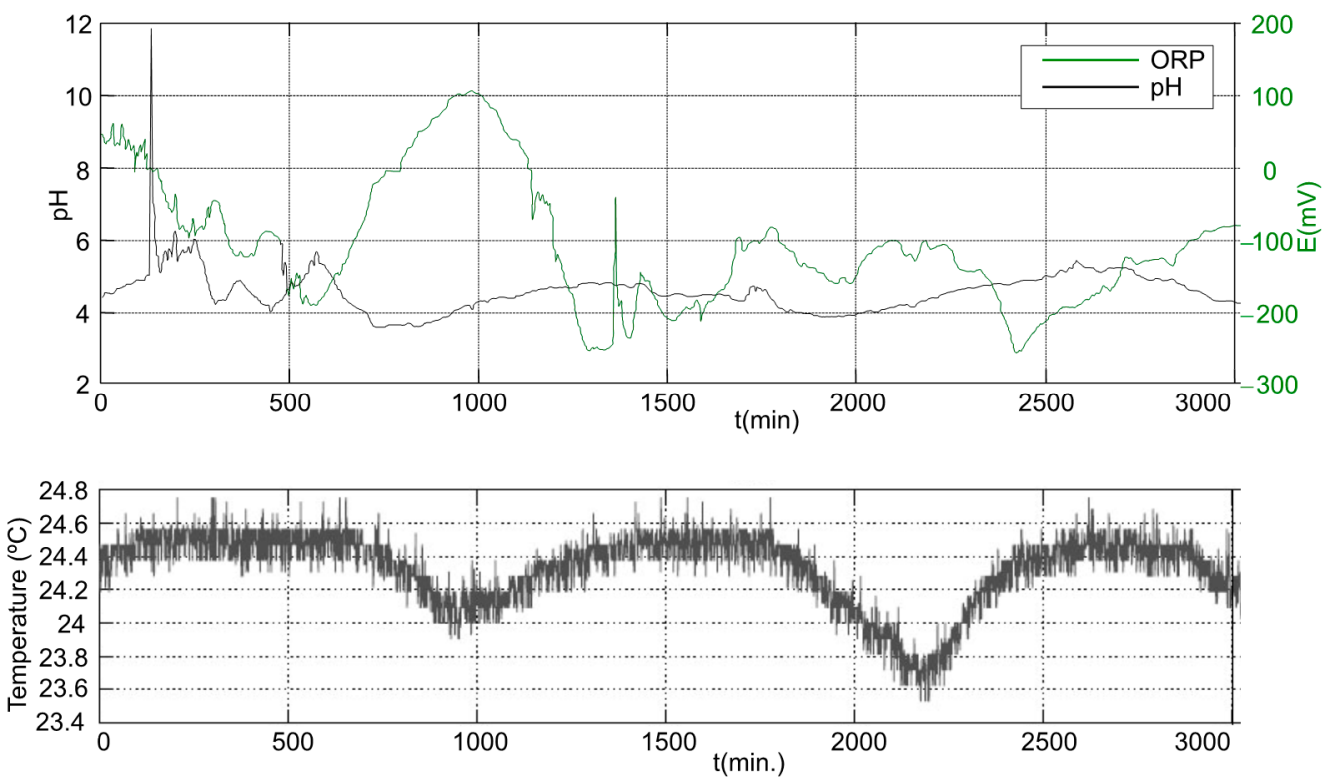

Figure 8. ORP, $\mathrm{pH}$, and temperature in the first period.

In general, the ORP graph shows a downward slope with a very irregular profile.

\subsubsection{Second Stage}

In this occasion, the system was fed back by $75 \mathrm{~mL}$ of a new mixing (see Table 2). From Figure 9, it is observed, in the first third of the stage, a sharp fall in ORP, $-85 \mathrm{mV}$; it immediately increases until it reaches a maximum value, $40 \mathrm{mV}$, then it begins to decrease gradually. This may have occurred due to the supply of substrate indicating an increase in activity in the first third of the period recorded. The difference in feedstock could change the microbial community and dominant species in anaerobic digestion process. In relation to temperature, the ORP maintains the same vein as that in the previous case.

\subsubsection{Third Stage}

For this stage, the alkalinity in the reactor was increased by the adding $\mathrm{NaOH}$ mixed with the substrate in the follow feeding. The basic environment of the system reflects negative ORP values, between -300 and $-470 \mathrm{mV}$. The graph, Figure 10, shows a gradual decreasing trend of ORP along this period. It is due to the buffering capacity of anaerobic digestion. Similar results have been achieved by other authors [55-58]. 

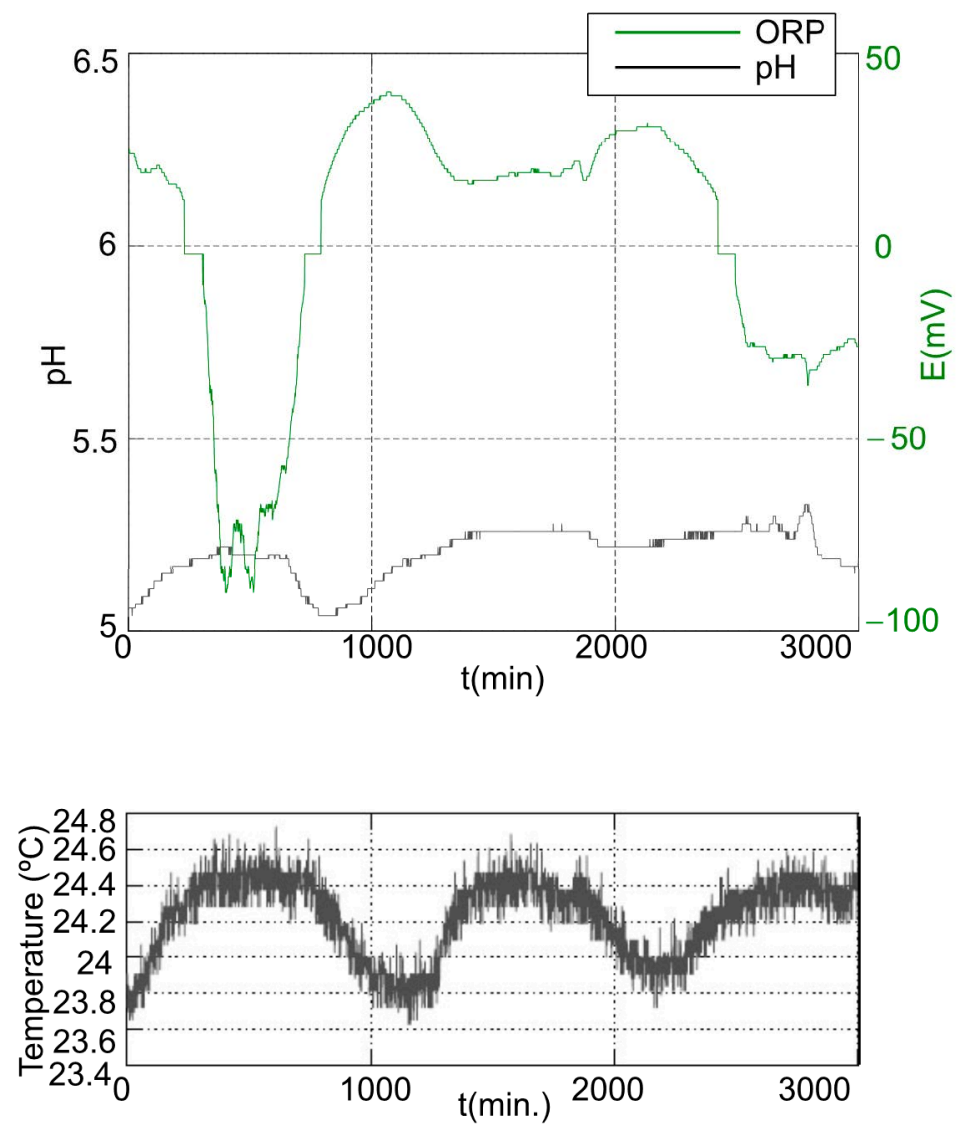

Figure 9. ORP, $\mathrm{pH}$, and Temperature in the second period.
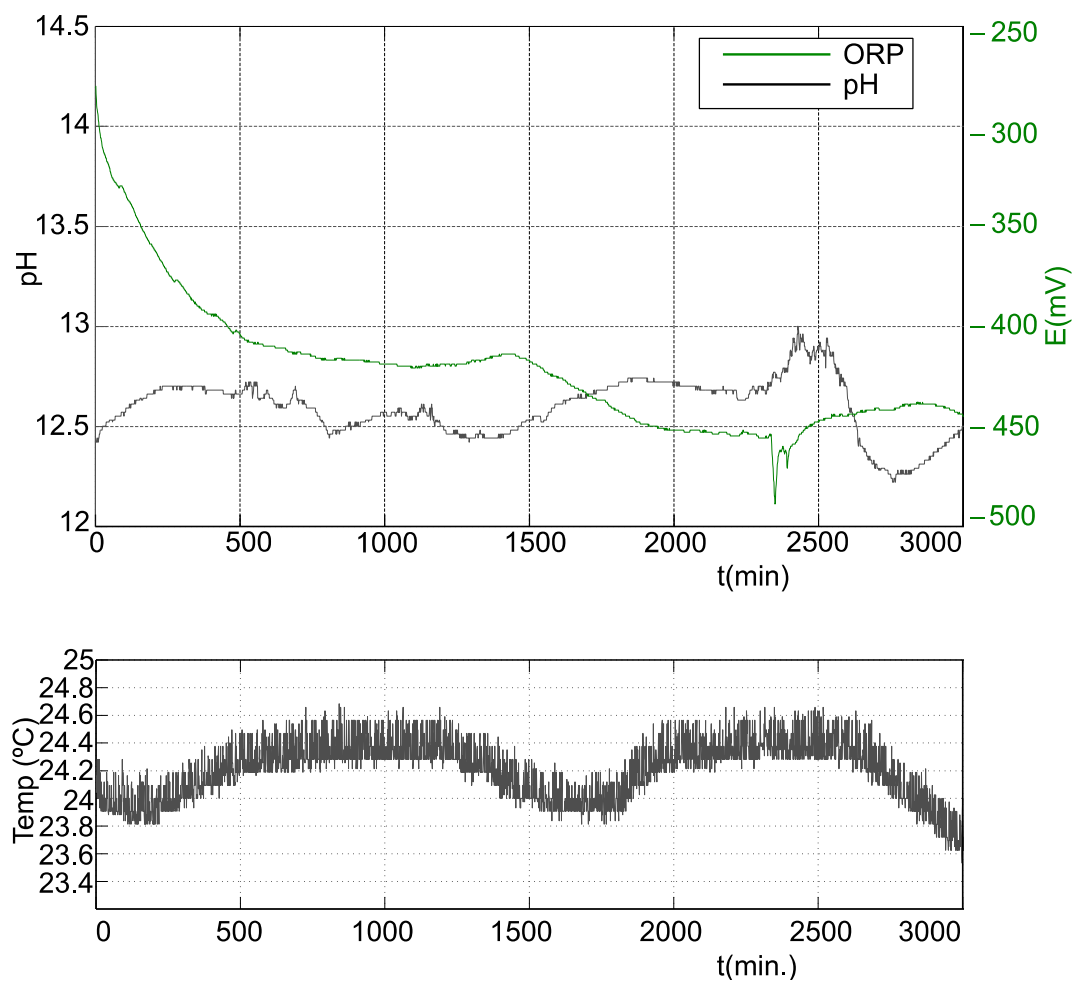

Figure 10. ORP, $\mathrm{pH}$, and Temperature in the third period. 


\section{Conclusions}

The proposed anaerobic biodigester monitored system works well, allowing for smallscale testing. Its use in research and teaching will allow the development of new research projects in the same way that it will help engineering students in their learning. With this design, it will be easy to determine the factors that can affect the growth of the anaerobic microorganism through the continuous data collection by the ORP, $\mathrm{pH}$, temperature, and pressure sensors. Subsequently, with the subsequent processing of the data, it is possible to make graphs to be contrasted with a previously proposed theoretical model, and at the same time it can be compared with the equations that govern its behavior (Nernst equation).

On the other hand, this design has been supported by flexible and easily accessible free software, this being an important advantage for students since it offers the possibility of adapting this experimental design to each specific case, and the whole software used is free and open source.

The results show that the experimental design is feasible for the control and data collection of magnitudes related to the growth of an anaerobic bacteria in a digester.

Finally, it should be remembered that the design and construction of a laboratory-scale biodigester, due to its economic viability, is a tool available to engineering students for the development of their knowledge and learning.

Author Contributions: Conceptualization, S.B.-E. and A.R.-M.; methodology, S.B.-E. and A.R.-M.; software, S.B.-E. and A.R.-M.; validation, F.L., A.R.-M., S.B.-E., J.V.-R. and C.M.-P.; formal analysis, S.B.-E. and A.R.-M.; investigation, S.B.-E. and A.R.-M.; resources, A.R.-M. and J.V.-R.; data curation, F.L. and A.R.-M.; writing - original draft preparation, F.L. and A.R.-M.; writing—review and editing, F.L., C.M.-P. and J.V.-R.; visualization, S.B.-E., F.L. and A.R.-M.; supervision, F.L., C.M.-P., J.V.-R. and A.R.-M.; project administration, S.B.-E., F.L. and A.R.-M.; funding acquisition, J.V.-R., F.L. and A.R.-M. All authors have read and agreed to the published version of the manuscript.

Funding: This research received no external funding.

Institutional Review Board Statement: Not applicable for studies not involving humans or animals. Informed Consent Statement: Informed consent was obtained from all subjects involved in the study.

Data Availability Statement: In this section, please provide details regarding where data supporting reported results can be found, including links to publicly archived datasets analyzed or generated during the study.

Acknowledgments: This research has been co-funded by the INTERREG V-A Cooperation SpainPortugal MAC (Madeira-Azores-Canarias) programme MITIMAC project MAC2/1.1a/263.

Conflicts of Interest: The authors declare no conflict of interest.

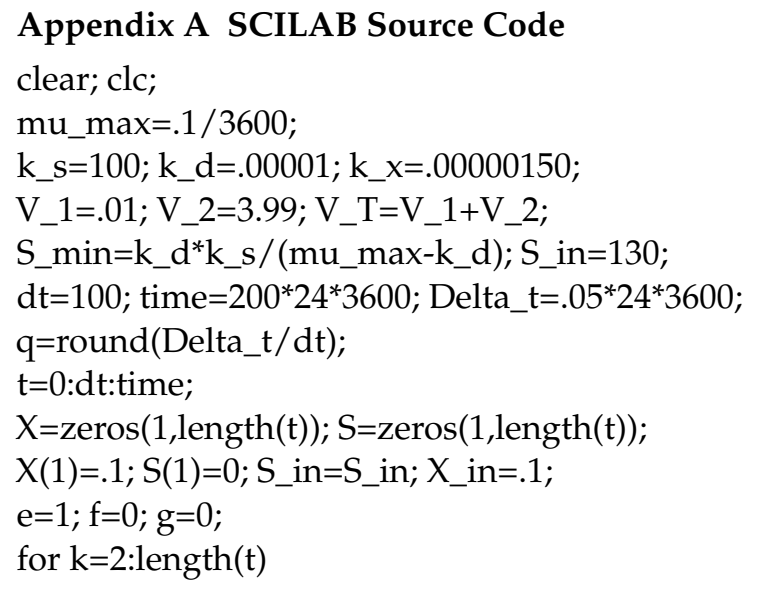


$\mathrm{f}=\mathrm{f}+1$

if $\mathrm{f}>=\mathrm{q} / /$ Impulse input

$\mathrm{S}(\mathrm{k}-1)=\left(\mathrm{V} \_2 * \mathrm{~S}(\mathrm{k}-1)+\mathrm{V} \_1 * \mathrm{~S} \_\right.$in $) / \mathrm{V} \_\mathrm{T}$;

$X(k-1)=\left(V_{-} 2^{*} X(k-1)+V \_1 * X \_\right.$in $) / V \_T$;

$\mathrm{f}=0$;

end

/ / Prediction step.

$X(k)=\left(1+\left(m u \_m a x * S(k-1) /\left(k \_s+S(k-1)\right)-k \_d\right)^{*} d t\right)^{*} X(k-1)$;

$\mathrm{S}(\mathrm{k})=\left(1-\mathrm{k} \_\mathrm{x}^{*} \mathrm{X}(\mathrm{k}-1) /\left(\mathrm{k} \_\mathrm{s}+\mathrm{S}(\mathrm{k}-1)\right)^{*} \mathrm{dt}\right)^{*} \mathrm{~S}(\mathrm{k}-1)$;

/ /nitialization and recursive correction steps.

While (e>=.01)

$\mathrm{X}=\mathrm{X}(\mathrm{k})$;

$\mathrm{s}=\mathrm{S}(\mathrm{k})$;

$X(k)=X(k-1)+d t / 2 *\left(\left(m u \_m a{ }^{*} S(k-1) /\left(k \_s+S(k-1)\right)-k \_d\right) * X(k-1)+\right.$

$\left.+\left(\mathrm{mu} \_\max * \mathrm{~S}(\mathrm{k}) /\left(\mathrm{k} \_\mathrm{s}+\mathrm{S}(\mathrm{k})\right)-\mathrm{k} \_\mathrm{d}\right)^{*} X(\mathrm{k})\right)$;

$\mathrm{S}(\mathrm{k})=\mathrm{S}(\mathrm{k}-1)-\mathrm{k} \_\mathrm{X}^{*} \mathrm{dt} / 2^{*}\left(\mathrm{~S}(\mathrm{k}-1) /\left(\mathrm{k} \_\mathrm{s}+\mathrm{S}(\mathrm{k}-1)\right)^{*} \mathrm{X}(\mathrm{k}-1)+\mathrm{S}(\mathrm{k}) /\left(\mathrm{k} \_\mathrm{s}+\mathrm{S}(\mathrm{k})\right)^{*} \mathrm{X}(\mathrm{k})\right)$; $\mathrm{e}=\operatorname{sqrt}\left((\mathrm{x}-\mathrm{X}(\mathrm{k}))^{\wedge} 2+(\mathrm{s}-\mathrm{S}(\mathrm{k}))^{\wedge} 2\right)$;

end

end

\section{Appendix B Microcontroller Source Code (Arduino)}

/ /*****Digital inputs for $\mathrm{pH}$ y ORP****

\#include <SoftwareSerial.h> / / add the soft serial libray

\#define rxph 4 / / set the RX pin to pin 2

\#define txph 5 / / set the TX pin to pin 3

\#define rxorp 2\#define txorp 3

/ / ${ }^{* * * *} \mathrm{pH}$ data ${ }^{* * *}$

SoftwareSerial phserial(rxph, txph); / / enable the soft serial port

String inputstringph $=$ "'"; / / string to hold incoming data from the PC

String sensorstringph $=$ " $"$; / / a string to hold the data from the Atlas Scientific product boolean input_stringcompleteph $=$ false;/ / have we received all the data from the PC

boolean sensor_stringcompleteph = false; / / have we received all the data from the Atlas

Scientific product

/ / ****ORP data***

SoftwareSerial orpserial(rxorp, txorp);

String inputstringorp $=$ " " ; / / a string to hold incoming data from the PC

String sensorstringorp $=$ " " ; / / a string to hold the data from the Atlas Scientific product boolean input_stringcompleteorp = false; / / have we received all the data from the PC boolean sensor_stringcompleteorp = false;//have we received all the data from the Atlas Scientific product

// ${ }^{* * * * A \text { Analog inputs }}{ }^{* * *}$

String sensorpresion $={ }^{\prime \prime \prime}$;// presion

float ntcbiodig $=0$; / / termistor NTC lectura sistema de control

float ntcext=0; / / termistor NTC lectura entorno

int analogPin $1=\mathrm{A} 1$; / / definimos los pines de entrada para la temperatura entorno

int analogPin2 = A2;//definimos los pines de entrada para la temperatura sistema

/ / *** SETUP ****

void setup ()$\{/ /$ set up the hardware

Serial.begin(9600); 
phserial.begin(9600); / / set baud rate for software serial port to 38400

orpserial.begin(9600);

phserial.print(" $\left.r \backslash r^{\prime \prime}\right)$;

orpserial.print(" $\mathrm{r} \backslash \mathrm{r}$ ");

phserial.print(" $\left.r \backslash r^{\prime \prime}\right)$;

orpserial.print(" $\mathrm{r} \backslash \mathrm{r}$ ”);

inputstringph.reserve(5); / / set aside some bytes for receiving data from the PC sensorstringph.reserve(30); / / set aside some bytes for receiving data from Atlas Scientific product

inputstringorp.reserve(5);/ / set aside some bytes for receiving data from the PC sensorstringorp.reserve(30);

pinMode(analogPin1, INPUT); //def de los pines de entrada

pinMode(analogPin2, INPUT);

\}

$/ /^{* * * *} \operatorname{loop}{ }^{* * * *}$

void loop ()\{

$/ /^{* * * * * * \text { Digital inputs }}{ }^{* * * *}$

delay(60000);

input_stringcompleteph = true;

input_stringcompleteorp = true;

inputstringph="r $\backslash \mathrm{r}$ ";

inputstringorp $=" r \backslash \mathrm{r}$;

bool mandar=true;

$/ /^{* * * * * * *} \mathrm{pH}^{* * * * *}$

if (input_stringcompleteph) \{ / if a string from the PC has been recived in its entierty phserial.print(inputstringph); //send that string to the Atlas Scientific product inputstringph $=$ " $;$; / / clear the string:

input_stringcompleteph $=$ false; $/ /$ reset the flage used to tell if we have recived a completed string from the PC 
\}

while(mandar)\{

phserial.listen();

while (phserial.available() $>0)\{/ /$ while a char is holding in the serial buffer

char inchar $=($ char $)$ phserial.read ()$; / /$ get the new char

sensorstringph $+=$ inchar; / / add it to the sensorstringph

if $\left(\right.$ inchar $\left.=={ }^{\prime} \backslash \mathrm{r}^{\prime}\right)\{$ sensor_stringcompleteph $=$ true; $\} / /$ if the incoming character is $\mathrm{a}\langle\mathrm{CR}\rangle$, set the flag

\}

if (sensor_stringcompleteph) \{ / / if a string from the Atlas Scientific product has been received in its entirety

Serial.print(sensorstringph); / / use the hardware serial port to send that data to the PC

sensorstringph $=$ " $;$; / clear the string:

sensor_stringcompleteph $=$ false; $/ /$ reset the flag used to tell if we have received a completed string from the Atlas Scientific product

mandar=false;

\}

\}

$/ /^{* * * * * *} \mathrm{ORP} P^{* * * * *}$

if (input_stringcompleteorp)\{ / / if a string from the PC has been recived in its entierty orpserial.print(inputstringorp); / / send that string to the Atlas Scientific product inputstringorp $="$ " ; / / lear the string:

input_stringcompleteorp = false;//reset the flage used to tell if we have recived a completed string from the PC

\}

mandar=true;

while(mandar)\{

orpserial.listen();

while (orpserial.available() $>0)\{$ / / while a char is holding in the serial buffer 
char inchar $=($ char)orpserial.read ()$; / /$ get the new char sensorstringorp $+=$ inchar; / / add it to the sensorstringorp

if $\left(\right.$ inchar $\left.==` \mathrm{r}^{\prime}\right)$ \{sensor_stringcompleteorp $=$ true; $\} / /$ if the incoming character is $\mathrm{a}\langle\mathrm{CR}\rangle$, set the flag

\}

$/ /^{* * * * * * A n a l o g i c ~ i n p u t s * * * * *}$

$/ /^{* * * * * *}$ THERMISTOR ${ }^{* * * * *}$

int ntcext=analogRead(analogPin2); / / leemos

$/ / /^{* * * * * * \text { TERMISTOR SISTEMA }}{ }^{* * * * *}$

int ntcbiodig=analogRead(analogPin1); // leemos

$/ /^{* * * * *}$ print ${ }^{* * * *}$

int sensorpresion $=$ analogRead(A0); / / lee valor de presion

if (sensor_stringcompleteorp) $\{/$ /if a string from the Atlas Scientific product has been received in its entirety

Serial.print(sensorstringph);//use the hardware serial port to send that data to the PC

Serial.print(","); / / use the hardware serial port to send that data to the PC

Serial.print(sensorstringorp);

Serial.print(“,",);

Serial.print(sensorpresion); // imprime valor de presion

Serial.print(“",");

Serial.print(ntcext);

Serial.print(“",");

Serial.println(ntcbiodig);

sensorstringorp $={ }^{\prime \prime \prime} ; / /$ clear the string:

sensor_stringcompleteorp = false; / / reset the flag used to tell if we have received a completed string from the Atlas Scientific product

mandar=false;

\}

\} 


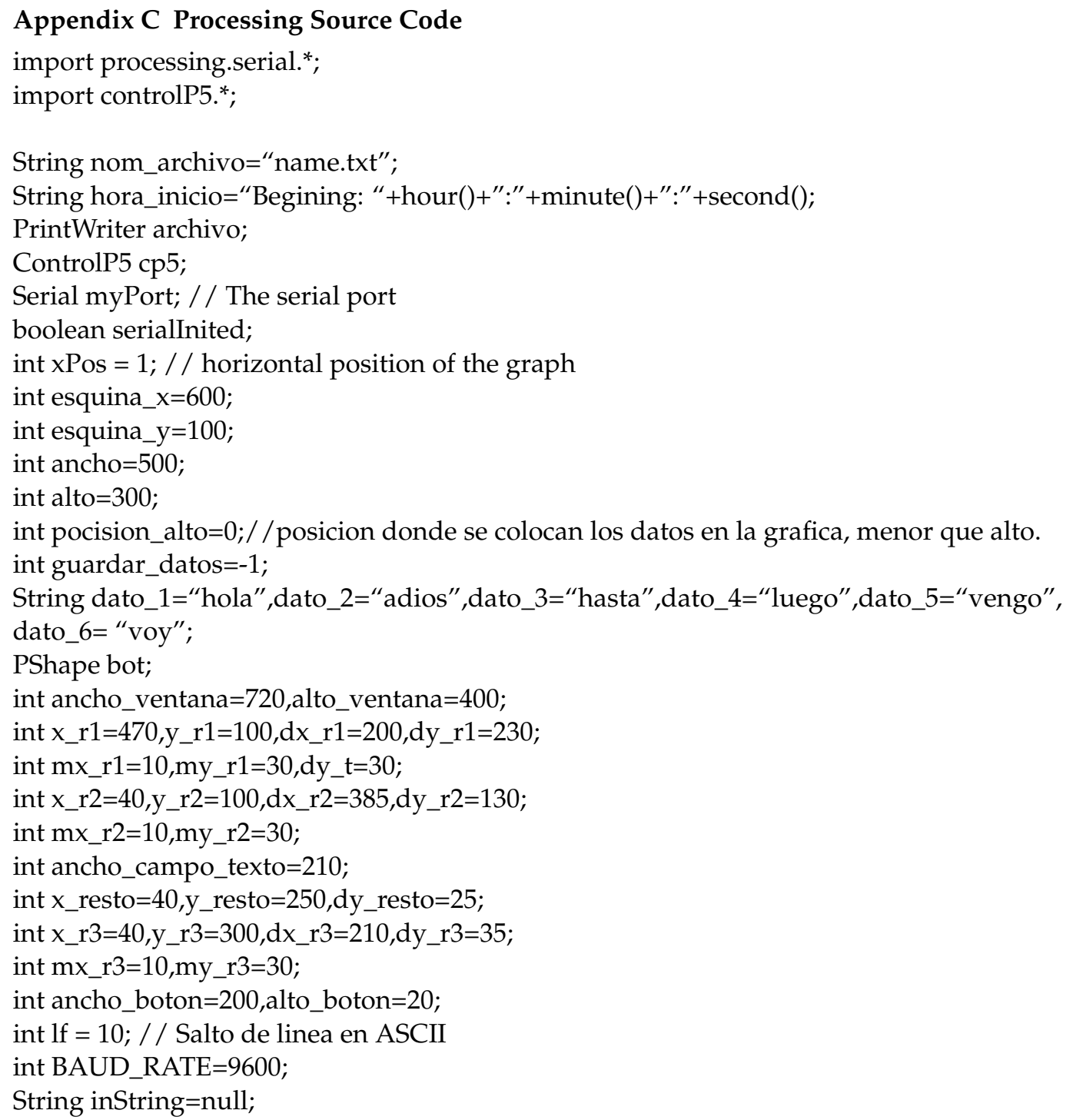

void setup () \{

cp5 = new ControlP5(this);

cp5.addButton("Save_data")

.setValue(0)

.setPosition(x_resto,y_resto)

.setSize(ancho_boton,alto_boton) 


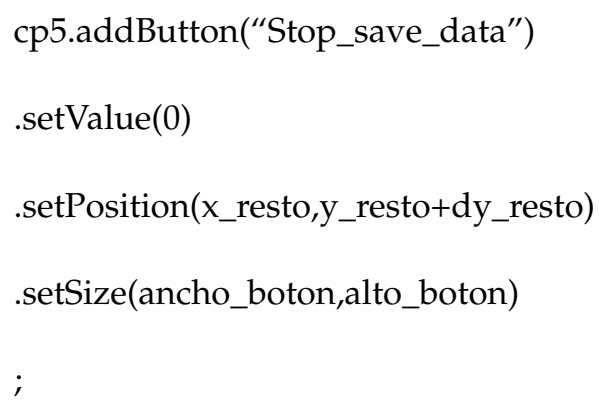




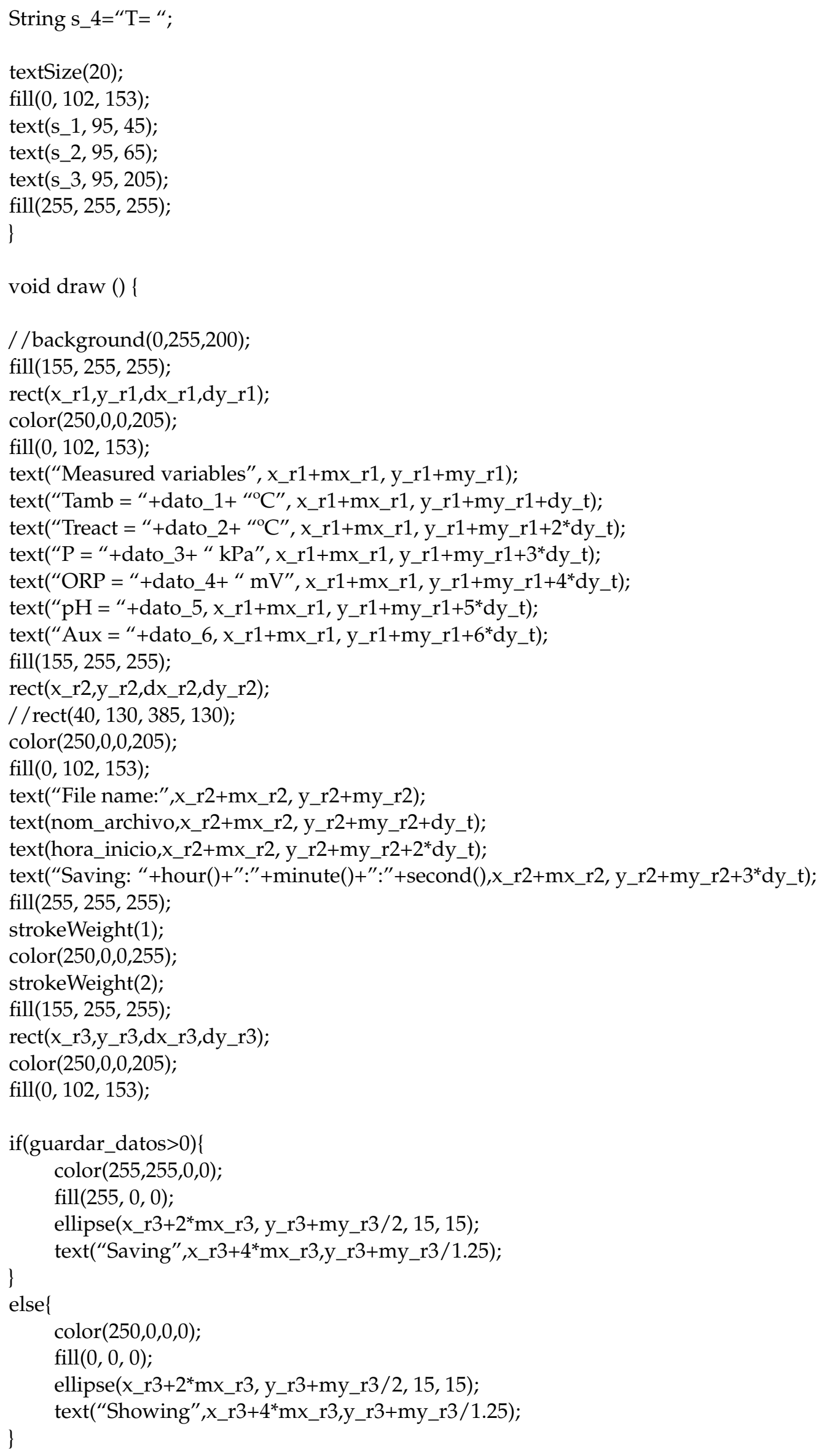




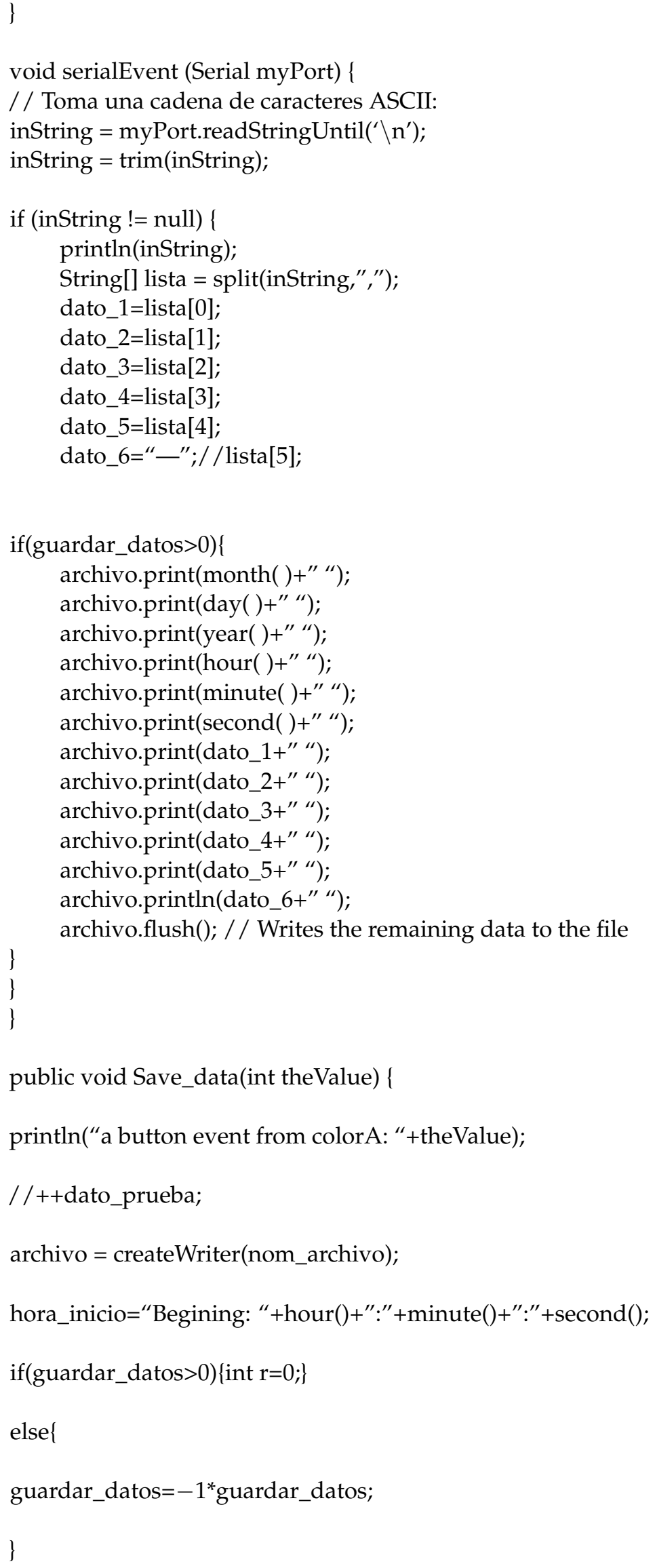




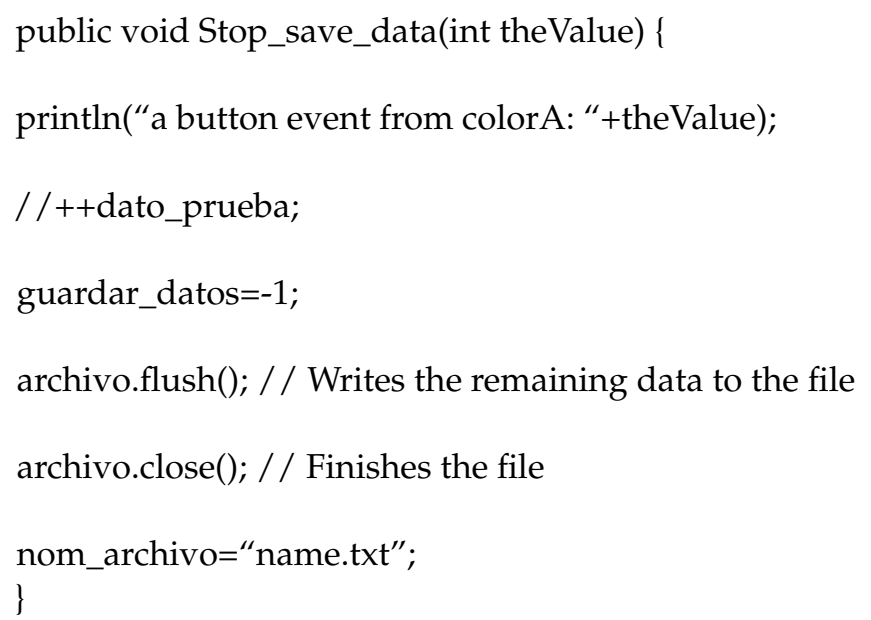

\section{References}

1. Brito-Espino, S.; Ramos-Martín, A.; Pérez-Báez, S.O.; Mendieta-Pino, C.; Leon-Zerpa, F. A Framework Based on Finite Element Method (FEM) for Modelling and Assessing the Affection of the Local Thermal Weather Factors on the Performance of Anaerobic Lagoons for the Natural Treatment of Swine Wastewater. Water 2021, 13, 882. [CrossRef]

2. Cano, E.; Ruiz, J.G.; Garcia, I.A. Integrating a learning constructionist environment and the instructional design approach into the definition of a basic course for embedded systems design. Comput. Appl. Eng. Educ. 2015, 23, 36-53. [CrossRef]

3. Garcia, I.A.; Cano, E.M. Designing and implementing a constructionist approach for improving the teaching-learning process in the embedded systems and wireless communications areas. Comput. Appl. Eng. Educ. 2014, 22, 481-493. [CrossRef]

4. Available online: http://www.atago.net/Spanish/download.htmlRX-7000i (accessed on 11 June 2021).

5. Refractómetro Digital Automático Atago. Available online: http://www.atago.net/Spanish/download.html (accessed on 14 June 2021).

6. Jagnow, G.; Dawind, W. Biotecnología: Introducción Con Experimentos Modelo; Acribia S.A.: Zaragoza, Spain, 1991.

7. Liu, C.-G.; Xue, C.; Lin, Y.-H.; Bai, F.-W. Redox potential control and applications in microaerobic and anaerobic fermentations. Biotechnol. Adv. 2013, 31, 257-265. [CrossRef]

8. Madsen, M.; Holm-Nielsen, J.B.; Esbensen, K.H. Monitoring of anaerobic digestion processes: A review perspective. Renew. Sustain. Energy Rev. 2011, 15, 3141-3155. [CrossRef]

9. Mekic, E.; Djokic, I.; Zejnelagic, S.; Matovic, A. Constructive approach in teaching of voip in line with good laboratory and manufacturing practice. Comput. Appl. Eng. Educ. 2016, 24, 277-287. [CrossRef]

10. Pantaleo, A.; De Gennaro, B.; Shah, N. Assessment of optimal size of anaerobic co- digestion plants: An application to cattle farms in the province of bari (Italy). Renew. Sustain. Energy Rev. 2013, 20, 57-70. [CrossRef]

11. Atlas Scientific. Atlas Scientific. Orpatlas. Available online: https://atlas-scientific.com/?gclid=EAIaIQobChMIvbPk803Z8 gIVied3Ch03AgqaEAAYASAAEgKLzPD_BwE (accessed on 19 July 2021).

12. Sorathia, K.; Servidio, R. Learning and experience: Teaching tangible interaction \& edutainment. Procedia-Soc. Behav. Sci. 2012, 64, 265-274.

13. Taylhardat Arjona, L.A. El biogas. Fundamentos e Infraestructura Rural; Instituto de Ingenieria Agri- cola; Facultad de Agronomia U.C.V: Maracay, Venezuela, 1986.

14. Leon, F.; Ramos, A.; Vaswani, J.; Mendieta, C.; Brito, S. Climate Change Mitigation Strategy through Membranes Replacement and Determination Methodology of Carbon Footprint in Reverse Osmosis RO Desalination Plants for Islands and Isolated Territories. Water 2021, 13, 293. [CrossRef]

15. Products for USB Sensing and Control. Products for Usb Sensing and Control. Available online: www.phidgets.com (accessed on 1 July 2021).

16. Parralejo, A.; Royano, L.; González, J.; González, J. Small scale biogas production with animal excrement and agricultural residues. Ind. Crops Prod. 2019, 131, 307-314. [CrossRef]

17. Holm-Nielsen, J.; Seadi, T.A.; Oleskowicz-Popiel, P. The future of anaerobic digestion and biogas utilization. Bioresour. Technol. 2009, 100, 5478-5484. [CrossRef]

18. Park, J.H.; Park, J.H.; Lee, S.H.; Jung, S.P.; Kim, S.H. Enhancing anaerobic digestion for rural wastewater treatment with granular activated carbon (GAC) supplementation. Bioresour. Technol. 2020, 315, 123890. [CrossRef] [PubMed]

19. Jiang, Y.; Bebee, B.; Mendoza, A.; Robinson, A.K.; Zhang, X.; Rosso, D. Energy footprint and carbon emission reduction using off-the-grid solar-powered mixing for lagoon treatment. J. Environ. Manag. 2018, 205, 125-133. [CrossRef] [PubMed]

20. Duan, N.; Zhang, D.; Khoshnevisan, B.; Kougias, P.G.; Treu, L.; Liu, Z.; Lin, C.; Liu, H.; Zhang, Y.; Angelidaki, I. Human waste anaerobic digestion as a promising low-carbon strategy: Operating performance, microbial dynamics and environmental footprint. J. Clean. Prod. 2020, 256, 120414. [CrossRef] 
21. Mendieta-Pino, C.A.; Ramos-Martin, A.; Perez-Baez, S.O.; Brito-Espino, S. Management of slurry in Gran Canaria Island with full-scale natural treatment systems for wastewater (NTSW). One year experience in livestock farms. J. Environ. Manag. 2019, 232, 666-678.

22. Muga, H.; Mihelcic, J. Sustainability of wastewater treatment technologies. J. Environ. Manag. 2008, 88, 437-447. [CrossRef]

23. $\mathrm{Wu}, \mathrm{B}$;; Chen, Z. An integrated physical and biological model for anaerobic lagoons. Bioresour. Technol. 2011, 102, 5032-5038. [CrossRef] [PubMed]

24. $\mathrm{Wu}, \mathrm{B}$. Advances in the use of CFD to characterize, design and optimize bioenergy systems. Comput. Electron. Agric. 2013, 93, 195-208. [CrossRef]

25. Donoso-Bravo, A.; Sadino-Riquelme, C.; Gómez, D.; Segura, C.; Valdebenito, E.; Hansen, F. Modelling of an anaerobic plug-flow reactor. Process analysis and evaluation approaches with non-ideal mixing considerations. Bioresour. Technol. 2018, 260, 95-104.

26. Rajeshwari, K.; Balakrishnan, M.; Kansal, A.; Lata, K.; Kishore, V. State-of-the-art of anaerobic digestion technology for industrial wastewater treatment. Renew. Sustain. Energy Rev. 2000, 4, 135-156. [CrossRef]

27. Lauwers, J.; Appels, L.; Thompson, I.P.; Degrève, J.; Impe, J.F.V.; Dewil, R. Mathematical modelling of anaerobic digestion of biomass and waste: Power and limitations. Prog. Energy Combust. 2013, 39, 383-402. [CrossRef]

28. Wade, M.; Harmand, J.; Benyahia, B.; Bouchez, T.; Chaillou, S.; Cloez, B. Perspectives in mathematical modelling for microbial ecology. Ecol. Model. 2016, 321, 64-74. [CrossRef]

29. Batstone, D.; Keller, J.; Angelidaki, I.; Kalyuzhnyi, S.; Pavlostathis, S.; Rozzi, A.; Sanders, W.; Siegrist, H.; Vavilin, V. The IWAAnaerobic Digestion Model No 1 (ADM1). Water Sci. Technol. 2002, 45, 65-73. Available online: https://library.lanl.gov/cgibin/getfile?00285556.pdf (accessed on 1 September 2020). [CrossRef]

30. Kleerebezem, R.; van Loosdrecht, M.C.M. Critical analysis of some concepts proposed in ADM1. Water Sci. Technol. 2006, 54, 51-57. [CrossRef] [PubMed]

31. Li, D.; Lee, I.; Kim, H. Application of the linearized ADM1 (LADM) to lab-scale anaerobic digestion system. J. Environ. Chem. Eng. 2021, 9, 105193. [CrossRef]

32. Fleming, J.G. Novel Simulation of Anaerobic Digestion Using Computational Fluid Dynamics. Ph.D. Thesis, North Carolina State University, Raleigh, NC, USA, 2002.

33. Goodarzi, D.; Sookhak Lari, K.; Mossaiby, F. Thermal effects on the hydraulic performance of sedimentation ponds. J. Water Process. Eng. 2020, 33, 101100. [CrossRef]

34. Brito-Espino, S.; Ramos-Martín, A.; Pérez-Báez, S.; Mendieta-Pino, C. Application of a mathematical model to predict simultaneous reactions in anaerobic plug-flow reactors as a primary treatment for constructed wetlands. Sci. Total Environ. 2020, 713, 136244 [CrossRef]

35. Mahmudul, H.; Rasul, M.; Akbar, D.; Narayanan, R.; Mofijur, M. A comprehensive review of the recent development and challenges of a solar-assisted biodigester system. Sci. Total Environ. 2021, 753, 141920. [CrossRef] [PubMed]

36. Atelge, M.; Atabani, A.; Banu, J.R.; Krisa, D.; Kaya, M.; Eskicioglu, C.; Kumar, G.; Lee, C.; Yildiz, Y.; Unalan, S.; et al. A critical review of pretreatment technologies to enhance anaerobic digestion and energy recovery. Fuel 2020, 270, 117494. [CrossRef]

37. Tumilar, A.S.; Milani, D.; Cohn, Z.; Florin, N.; Abbas, A. A Modelling Framework for the Conceptual Design of Low-Emission Eco-Industrial Parks in the Circular Economy: A Case for Algae-Centered Business Consortia. Water 2021, 13, 69. [CrossRef]

38. Haßler, S.; Ranno, A.M.; Behr, M. Finite-element formulation for advection-reaction equations with change of variable and discontinuity capturing. Comput. Methods Appl. Mech. Eng. 2020, 369, 113171. [CrossRef]

39. Mirza, I.A.; Akram, M.S.; Shah, N.A.; Imtiaz, W.; Chung, J.D. Analytical solutions to the advection-diffusion equation with Atangana-Baleanu time-fractional derivative and a concentrated loading. Alex. Eng. J. 2021, 60, 1199-1208. [CrossRef]

40. Singh, S.; Bansal, D.; Kaur, G.; Sircar, S. Implicit-explicit-compact methods for advection diffusion reaction equations. Comput. Fluids 2020, 212, 104709. [CrossRef]

41. Zeng, L.; Chen, G. Ecological degradation and hydraulic dispersion of contaminant in wetland. Ecol. Model. 2011, 222, 293-300. [CrossRef]

42. Bozkurt, S.; Moreno, L.; Neretnieks, I. Long-term processes in waste deposits. Sci. Total Environ. 2000, 250, 101-121. [CrossRef]

43. Song, L.; Li, P.W.; Gu, Y.; Fan, C.M. Generalized finite difference method for solving stationary 2D and 3D Stokes equations with a mixed boundary condition. Comput. Math. Appl. 2020, 80, 1726-1743. [CrossRef]

44. Ukai, S. A solution formula for the Stokes equation in Rn+. Commun. Pure Appl. Math. 1987, 40, 611-621. [CrossRef]

45. Reddy, J.; Gartling, D. The Finite Element Method in Heat Transfer and Fluid Dynamics, 3rd ed.; CRC Press: Boca Raton, FL, USA, 2010; pp. 1-483.

46. Alvarez-Hostos, J.C.; Bencomo, A.D.; Puchi-Cabrera, E.S.; Fachinotti, V.D.; Tourn, B.; Salazar-Bove, J.C. Implementation of a standard stream-upwind stabilization scheme in the element-free Galerkin based solution of advection-dominated heat transfer problems during solidification in direct chill casting processes. Eng. Anal. Bound. Elem. 2019, 106, 170-181. [CrossRef]

47. Guldentops, G.; Van Dessel, S. A numerical and experimental study of a cellular passive solar façade system for building thermal control. Sol. Energy 2017, 149, 102-113. [CrossRef]

48. Lawrence, M.G. The Relationship between Relative Humidity and the Dewpoint Temperature in Moist Air: A Simple Conversion and Applications. Bull. Am. Meteorol. Soc. 2005, 86, 225-234. [CrossRef]

49. Çengel, Y. Heat Transfer: A Practical Approach. In McGraw-Hill Series in Mechanical Engineering; McGraw Hill Books: London, UK, 2003. 
50. Walton, G.N. Thermal Analysis Research Program Reference Manual; NBSIR, Department of Energy, Office of Building Energy Research and Development: Washington, DC, USA, 1983.

51. Monod, J. The Growth of Bacterial Cultures. Annu. Rev. Microbiol. 1949, 3, 371-394. [CrossRef]

52. Rosso, L.; Lobry, J.; Flandrois, J. An Unexpected Correlation between Cardinal Temperatures of Microbial Growth Highlighted by a New Model. J. Theor. Biol. 1993, 162, 447-463. [CrossRef] [PubMed]

53. Herus, V.A.; Ivanchuk, N.V.; Martyniuk, P.M. A System Approach to Mathematical and Computer Modeling of Geomigration Processes Using Freefem++ and Parallelization of Computations. Cybern Syst. Anal. 2018, 54, 284-292. [CrossRef]

54. Donoso-Bravo, A.; Bandara, W.; Satoh, H.; Ruiz-Filippi, G. Explicit temperature-based model for anaerobic digestion: Application in domestic wastewater treatment in a UASB reactor. Bioresour. Technol. 2013, 133, 437-442. [CrossRef]

55. Donoso-Bravo, A.; Retamal, C.; Carballa, M.; Ruiz-Filippi, G.; Chamy, R. Influence of temperature on the hydrolysis, acidogenesis and methanogenesis in mesophilic anaerobic digestion: Parameter identification and modeling application. Water Sci. Technol. 2009, 60, 9-17. [CrossRef]

56. Wang, R.; Lv, N.; Li, C.; Cai, G.; Pan, X.; Li, Y.; Zhu, G. Novel strategy for enhancing acetic and formic acids generation in acidogenesis of anaerobic digestion via targeted adjusting environmental niches. Water Res. 2021, 193, 116896. Available online: https: / / www.sciencedirect.com/science/article/pii/S0043135421000944 (accessed on 23 June 2021). [CrossRef]

57. Weißbach, M.; Drewes, J.E.; Koch, K. Application of the oxidation reduction potential (ORP) for process control and monitoring nitrite in a Coupled Aerobic-anoxic Nitrous Decomposition Operation (CANDO). Chem. Eng. J. 2018, 343, 484-491. Available online: https:/ / www.sciencedirect.com/science/article/pii/S1385894718303929 (accessed on 30 June 2021). [CrossRef]

58. Ao, T.; Chen, L.; Zhou, P.; Liu, X.; Li, D. The role of oxidation-reduction potential as an early warning indicator, and a microbial instability mechanism in a pilot-scale anaerobic mesophilic digestion of chicken manure. Renew. Energy 2021, 179, $223-232$. Available online: https:/ / www.sciencedirect.com/science/article/pii/S0960148121010521 (accessed on 1 July 2021). [CrossRef] 